\title{
Unsettling the Patriot: Troubled Objects of Masculinity and Nationalism
}

Cüneyt Çakırlar

(published in Queer Dramaturgies: International Perspectives on Where Performance Leads Queer, edited by Alyson Campbell and Stephen Farrier, Basingstoke: Palgrave MacMillan, 2015, pp. 81-97)

In his study of 'globalising influences' on Asian sexual identities, Dennis Altman argued that the internationalisation of gay identities should enable queer research 'to question the extent to which the forces of globalisation (both economic and cultural) can be said to produce a common consciousness and identity based on homosexuality' (1996: 79). Altman's problematisation could certainly be taken into account while reading the global travel of a contemporary queer art-work that engages with sexual dissidence. However, what Altman calls the 'global gaze' (1997) should always be subject to negotiation and contestation as well as transfiguration. I thus prefer to seek a way of interpreting an intellectual, artistic consciousness based on queerness or queer practice, in which the notion 'queer' would always already refuse an essentialising commonality based on universally fixed sexual identity categories. However, critiques of the 'Gay International' is also problematic in presupposing a radical alterity between the sexual epistemologies of the West and the rest: the former is overinterpreted as monolithicly imperialist and Islamophobic whereas the latter is taken as a passive overlocalised recipient subject to any socalled western incitement to discourse (Massad, 2002). Queer, in both cases, would still be a useful critical tool in terms of rethinking histories of sexuality and reevaluating methodological approaches to contemporary sexualities that go beyond identity categories and an unquestioned East-West division (Traub, 2008). 
The contemporary art scene in Turkey has gained considerable international visibility in recent decades. The post-2000s' expansion of art galleries and art collectors as well as the country's international networks have made the scene into a vital territory of cultural capital, in which artists and their collaborators working in neighbouring fields, such as academics and activists, channel their voices through art. The neoliberal regimes and political economies within this international traffic of art as capital deserves critical focus and this essay, however, utilises an in-depth reading of art-works by Erinç Seymen, one of the key figures within the young postjunta generation of artists in Turkey, to open up a discussion of the glocalisation/internationalisation of arts and queer practices. The academic, artistic and cultural visibility of these practices in Turkey opens up other critical possibilities to articulate the problematics of 'travel' and the 'translation' of sexual dissidence. The aim here is to examine the aesthetic discourse of embodiment in Seymen's art-practice by focusing on the ways in which his art-works refer to, critique and exploit the hegemonic intersections between militarism, nationalism, heteronormativity and masculinity in contemporary Turkey. Though sceptical of an unproblematically performed de-contextualisation of queer theories from its western referent, my reading of Seymen's artistic performance will investigate the possible strategies of translating and transposing queer aesthetics into a critical practice that insist not merely on a local political context but also engages with the geopolitics of global contemporary art market and its 'ethnographic turns'. 


\section{Nationhood and Queer Alliances:}

Erinç Seymen's Alliance (2009) depicts two bodies united by what appears to be a dildo on a black flag. At first glance, the encounter appears to be an amorous one, if the ambivalent facial expressions on the flag are taken to reveal joy, or ecstasy, and the merging of the hand of one figure with the leg of the other read as supplementing the joyful union as a loving touch. The title of the artwork enacts an indexical naming where the word alliance (ittifak) not only gestures to the bodily union but also, I argue, exploits the flag in marking it as a banal object of militarist nationalism. The flag, which generally 'seems to possess a reassuring normality ... a hegemonic unmarkedness, invisible embeddedness, within everyday life,' (Billig, 1996: 6) becomes radically visible through the homoeroticism evoked by Seymen's strategic use of sameness, symmetry, reciprocity and anal penetration applied to the textile. The artist himself underlines the ambivalence of the work: 'one can read this image as a sexual act or a scene of torture; even those who are punished by the most subjugatory apparatuses of power can construct alliances and produce (and then camouflage) pleasure out of those alliances in the hidden corners we may ignore' (Seymen in Uncu, 2009: n.p.). Whereas the figures can be interpreted as masochistic servants reiterating the performative of the flag, they may equally be read as amorous embodiments in a non-hegemonic exchange of pleasure juxtaposing the ideological status of the flag - that marker of hegemonic militarist masculinity in which they are embroidered. The artist states: 


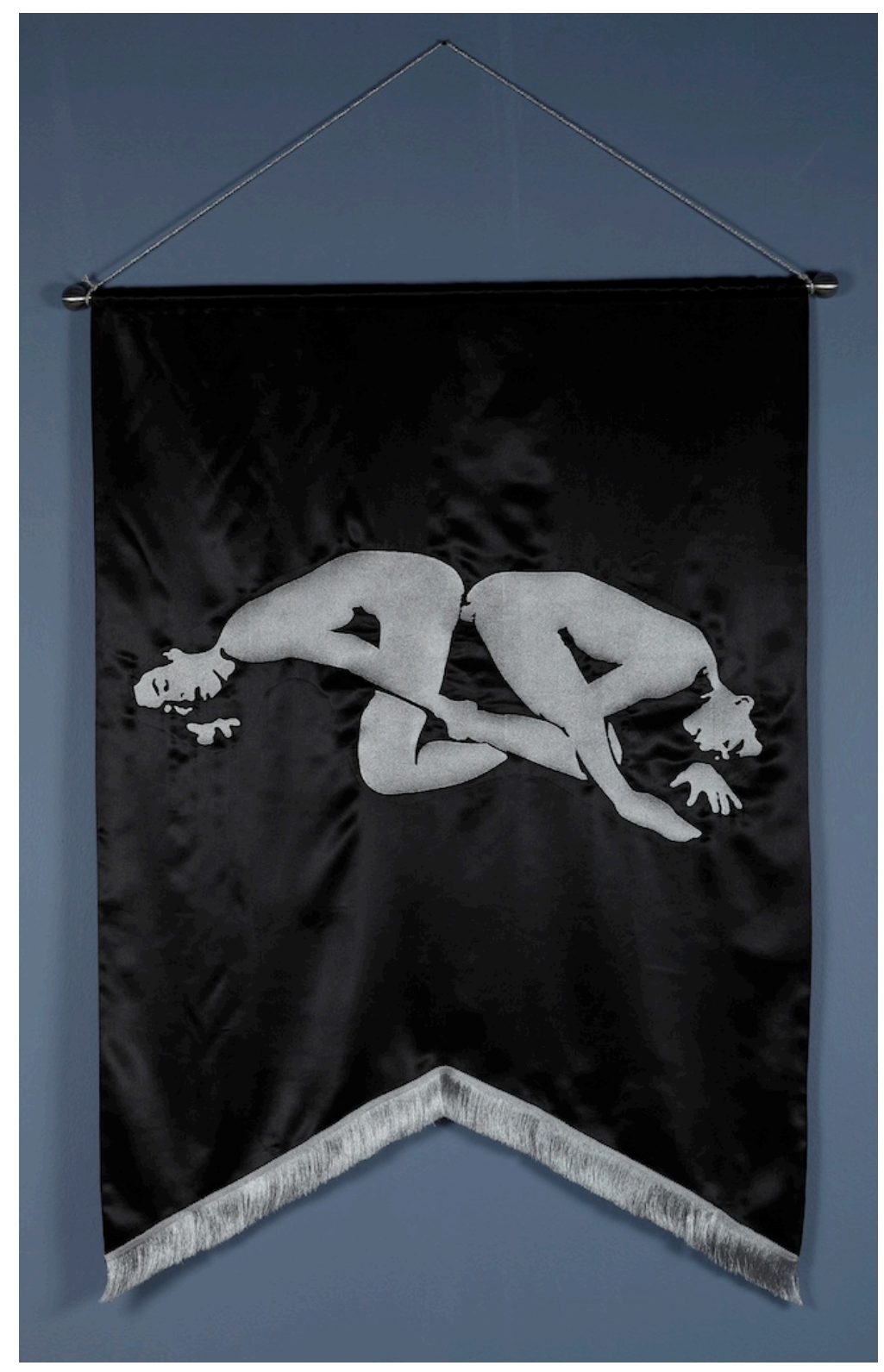

\section{Figure 1}

Erinç Seymen, Ittifak / Alliance (2009)

Embroidery on Satin, $150 \mathrm{~cm} \times 112 \mathrm{~cm}$

Reproduced with permission. Courtesy of the artist and RAMPA, Istanbul.

It is possible to argue that the interpenetration of the two bodies in Alliance the two lovers, the two captives, or the two victims of torture, if you like signifies an act that escapes hegemonic masculinity and hetero- or homonormative formulations of sexual relationality. A [double-sided] dildo does not have to be a sexual toy of punishment accommodated by a machist male to 
captivate two holes, two women, or two men in his harem. That dildo and the two holes in Alliance have the potential to disappoint the machist male with the bodily orifice swallowing the penile power by transforming itself into a vacuum. ${ }^{1}$

I am wary of reiterating a discourse that merely presupposes that any LGBTQ-based production in Turkey enacts a monolithically provincialised reality of violent homophobic oppression. Localising the artwork to its national referent and situating it within the sociopolitical constellations in Turkey where it was first exhibited in 2009, raises critical analytical possibilities that can interrogate the transposition of queer aesthetics into non-western contexts. However, such a localising practice of critique - a performative critical practice that ignores its object's international travel, indexing it within a national political context only - may run a discursive risk of imposing precarious constructs of neo-colonialism where globalised political discourses of gender and sexual liberation become 'the new yardsticks for democracy' and a new ideological means of racism and Islamophobia (Haritaworn, Tauqir and Erdem, 2009; see also Ahmed, 2011). Equally I am cautious not to replicate a call for the emancipation of LGBTQ subjects and to symptomise, envoice, or allegorise, a clash between the signifiers of democracy, militarism, modernisation and Islam. Seymen's critical voice, I believe, should not only be reduced to an unproblematised identity politics.

\footnotetext{
${ }^{1}$ This is an unpublished statement of the artist in response to the series of workshops I had convened at Istanbul Bilgi University and Bogazici University in the 2009-2010 academic term. I would like to thank him for his generosity in sharing his own reflections on Alliance and granting me permission to use these conversations in this article.
} 
The ideological constructs of such localisations in art criticism seem problematic especially when nationality is taken as the default referent, overwhelming other critical interpretations and possibilities of intersectional readings. A considerable part of Seymen's work uses allegorical objects; it recycles, appropriates and subverts gendered iconographies of nationalism. However, I wish to set a critical agenda of reading Seymen's art, aesthetics, visual culture and media as that which transposes queer alterity into Turkish cultural memory - and vice versa - through a constant disidentificatory distance working on and against the local/global binary (Muñoz 1999). Seymen's work may be said to enact the counter-enunciating momentum that Erden Kosova discusses in his critique of the post-junta politicisation of art practice by younger generation contemporary visual artists in Turkey: 'Instead of the universalist language of inter-nationalism, which claimed to transcend the constraints and attributed provinciality of local contexts, this new production pursued the decisive strategy of scuffling with all dimensions of its geography-culture' (Kosova, 2009: 2). I would add here that the artistic agenda of the young post-junta generation demonstrates a curious self-awareness of cultural globalisation within contemporary arts. ${ }^{2}$ Their art practice entails many layers of critical appropriation which do not escape or entirely forego the globalising imperatives of theory, politics and art-practice. Seymen here is one of the most significant figures whose artworks can lead to a productive debate on the

2 The military coup on 12 September 1980 marks the most repressive period of Turkey's recent history. As Nurdan Gürbilek also argues, the junta's violence has not only been about a practice acted upon all forms of political and cultural dissidence: it also literally inscribed its hegemony before its withdrawal through the constitution and deep institutionalisation (2011: 4). What this essay means by the word 'post-junta' does not necessarily presuppose a post-1980s period in Turkey which operates beyond militarism. I would argue that any dissidence returned from the repressed has hitherto been dependent on the military power. 
local/global knowledge within queer aesthetics as well as contemporary art criticism. His discourse can be neither reduced to an Occidentalist internalisation of the 'Gay International' (Massad, 2002) nor overinterpreted as a 'de-gayed' localisation of an indigenous homoeroticism. The artworks facilitate, if not embody, dynamic scales of interpretation in queer critique.

\section{Scaling/"Regioning" in Queer Critique"}

While the artwork Alliance can be considered to perform a queer intervention into the hegemonic masculinity of militarist nationalism in contemporary Turkey, it still seems to bear a delocalising edge in terms of its resonance with Leo Bersani's reclamation of queer aesthetics as ascesis, or the 'redemptive reinvention of sex' (1987: 215) by celebrating the queer male's obsession with sex, which 'never stops re-presenting the internalised phallic male as infinitely loved object of sacrifice' (222). The queer political agenda of Seymen's Alliance, the very surface of the artwork (the homo-erotics of sameness and the ironic use of symmetry), crystallises around 'devalorisation of difference, a notion of difference not as a trauma to be overcome ... but rather as a nonthreatening supplement to sameness' (Bersani, 1996: 7). The artist's performative, propagandist address at an imagined mode of alliance, an imagined queer nationness, through the use of double-ended dildo, enacts an 'expansive sense of gayness in the spirit of ... queerness as an especially capacious and looser understanding between sexuality and selfhood' (Dean, 2000: 278). Queer in this regard, functions within and beyond the reference of homosexuality and identity politics. It is a gender - and sexuality - conscious 
strategy of making strange through a performative deployment of the ambiguous, the erotic and the promiscuous. Picking up on what Denis Flannery calls Mapplethorpe's 'queer aesthetic of the pair, Seymen's act of queering operates as 'reversal, action, impact, the interface between power and category, critique' (Flannery, 2005: 268) which attempts to perverse, to sexually mark, or make strange/visible, the unmarkedness of the normative economies of gender and sexuality within power relations.

If queer analysis gives an account of sexual subjectivities under the disembedding forces of globalisation, it should enact a dynamic, multi-scalar approach that considers different scalar registers (e.g. local, regional, national, global) as well as their cross-nurturing intersections. I thus would like my critical analysis to constantly switch scales and oscillate between such localising and universalising discourses. I take Seymen's art as a theoretical object in itself, as an image of thought which allows a critical examination of queer as a travelling, self-scaling concept (Çakirlar, 2011b; 2013). What I am after is to depart from a possible critical mode of what Irit Rogoff (2010) conceptualises as 'regional imagining' and to read queer aesthetics via non-hegemonic conversations between the art object and the geopolitics of critical theory. Rogoff regards this as

an alternative, non-identitarian practice, a practice that does not feel obliged to root one exclusively in either material histories or in purely fantastical projections, opting instead to piece together a location from fragments of what was and of what might be, simultaneously; an attempt both to activate and to actualise notions of location away from being 'located' by an authority of knowledge or a political authority (being Turkish, being Middle Eastern, being of the Muslim world, for example) and towards a notion of '(self)-regioning' ... which focuses not on trying to figure out what one's identity might be as a 
given, but on trying to produce a set of relationships in the world that might locate one (2010: 48).

Although the artwork cannot be presupposed to implicate explicitly a discourse functioning within its geographical specificity, its anti-militarist anti-statist edge within a queer mode of sabotage is clearly visible. Seymen's Alliance is paradigmatic of a self-regioning critical mode that 'makes possible other forms of territorial affinity rather than belonging' (Rogoff, 2010: 54). The artwork imagines a queer politics of community and nation. Meanwhile it bears an allegorical potential to elaborate its surface when regionalised to a contemporary post-junta Turkish sociopolitical context. In appropriating the machist representation of the bottom, and doubling the bottomness in excluding the penetrator and reducing the penetration into dildoic detail, Alliance bends the normative logic of penetration, which can be read through the hegemonic administrative discourse of the Turkish military labelling the homosexual body as 'unfit for service'. However, the 'citizens' of Alliance incorporate neither a clear image of victimhood nor an explicit reference to Turkey. In its strategic, critically generative ambiguity and subtlety, the art work queers the grand signifiers of nationalism, militarism, heteronormativity and hegemonic masculinity.

\section{Mourning Local Queer Histories: Reclamation and Sodomitical Sublimes}

A similar queer visual discourse incorporating elements of sabotage, exposure, exploitation, and ambivalence is dramatically at play in my next case study: Seymen's Portrait of a Pasha (2009). In the late 1980s, so the story goes, the Turkish general Kenan Evren, who led the 1980 coup d'état in Turkey, encountered the 
popular Turkish music icon known popularly as 'the Pasha of Art', Zeki Müren. Müren was a much respected singer, well known, in later periods of his career, for his extravagant costumes on stage and his mannered performance almost in drag. This imagined encounter is followed by a conversation initiated by the general's curiosity about the honorary title bestowed on Müren by the Turkish public, namely pasha, a title reserved under the Ottoman sultanate for high-ranking military personnel. Evren asks Müren why this symbolic title had been given to him. After some hesitation, and at the general's insistence, Müren answers the question: 'This nation was so angry about what you did during the military coup, but they couldn't be very open with their anger. Rather than calling you faggots (ibne), they called me pasha'.

Müren's sly response to the general here seems to playfully engage with the nationalist accents of homophobic masculinity and militarism. The non-evidential but viral propagation of the joke acquired the status of gossip and seemed to presuppose another gossipy 'truth': Müren's gayness. An effect of phantasmatic investment in testimony, evidence and historical truth telling, the stubborn everyday presence of this joke exemplifies a collective 'signature' of Turkish cultural memory. Implicating Zeki Müren, never publicly 'out-ed' as gay, both the above story and Seymen's art-work enable a discursive articulation of the sexually deviant content of the joke as a de-closeting performative speech act of disclosure with regard to marginal sexual identities and practices. 
The artistic performance in Seymen's Portrait of a Pasha (2009) is inspired by the story of Müren and the general, and the art-work's reclamation of this event attempts to play with the very ontological foundations of straight masculinity and national identity. It treats the encounter as an imagined confrontation between the two oppositional, culturally phantasmatic bodies, the soldier-citizen and the male homosexual, within the history of the modern/ised Turkish subject. In this particular national context, Seymen reanimates and reembodies that moment in order to queer the identification with militarist masculinity. Thus, what the art work might also mobilise is a quest for a queer possibility for translating a rumoured, thus fantasised, encounter with a deviant artistic pleasure and, in doing so, disclosing 'the homosexual' as the repudiated, but constitutive abject-other of the militarist nationalist masculinity.

Seymen's Portrait appears to put an emphasis on the ritualistic process of making the portrait - by means of supplementing the artwork with a single screen video installation. In the video, the image of Zeki Müren is roughly portrayed by the artist on a canvas covering a white wooden panel. In fact, we see that the panel is a target in a shooting range being shot at by a marksman. Thus, the finished portrait appears from the bulletholes on the panel, the canvas having been removed. By canvas, I do not mean a conventional sheet or surface that uniformly covers the wooden panel. The artist's sketch of Zeki Müren on the panel is neither a laboriously crafted drawing nor a mechanically reproduced copy. Seymen uses yellow sticky dots on black background to produce target points for the marksman's performance of 
shooting. The word 'canvas' is thus used here as the skin of the artist's aesthetic authority, a minimal surface of artistic intentionality/mind or, in other words, a projective skin of the artist's bodily agency removed from the final product. The remaining bullet holes seem to embody the flirtatious pose/gaze of Zeki Müren's eyes. I wish to explore more here Seymen's performative translation of this pashato-pasha encounter, into queer art practice through the libidinal appropriation of 'the penetrative'.

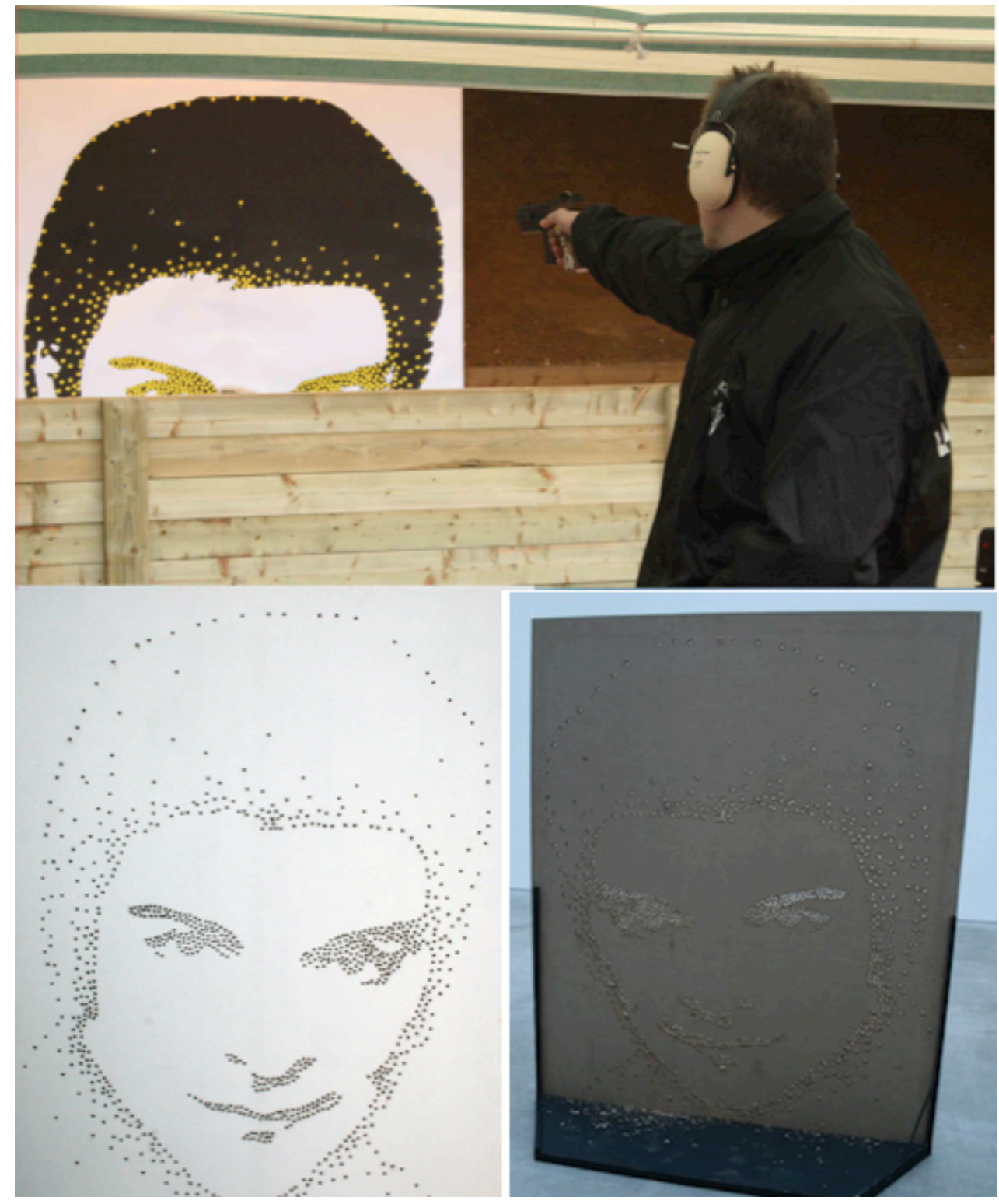


Figure 2.

Erinç Seymen, Portrait of a Pasha (2009), screenshot from the video, exhibited in Istanbul, Traversée (2009), Palais des Beaux Arts, Lille, France. Courtesy of the artist and RAMPA, Istanbul.

Reproduced with permission.

The use of Müren's iconic image in Portrait of a Pasha does not work to assign the figure to the critical, and resistant, agency of a marginal gender subjectivity, but enables this popular queer image to disclose and re-enact the hypocrisy of the Turkish project of nation building and its heteronormative urge in the sociopolitical treatment of the queer citizen. ${ }^{3}$ To call Müren pasha does not imply any sense of irony: he was, in fact, widely admired as a performer. After his unforgettable performance in a famous 1969 concert at the ancient theatre Aspendos, Turkish admirers called him 'the Pasha of Art' (Stokes 2003). It is still very hard and ambitious to identify and read the initial discursive urge of the Turkish public to name the artist as pasha. Although this was to reward Müren and his memorable achievement in performance on the Aspendos stage, the contrast between the artist's queer presence and performative excess on stage, and the gendered status of the public's 'gift', attaching a masculine and militarist virtue to the artistic achievement with the very name pasha, is nonetheless striking. This honouring title, I contend, demonstrates a way of managing the 'Queer Müren' by negotiating with and normalising his professional artistic achievement and persona: a masculinist mode of tolerance through camouflaging queer sexuality with the figure's status as national-cultural asset and further instrumentalising Müren's own enactment of the closet. In his work on the cultural image of Müren, the ethnomusicologist Martin

\footnotetext{
${ }^{3}$ Notably, after his death from a heart attack during a live performance on stage in 1996, it was discovered that Zeki Müren had left a considerable portion of his wealth to the Turkish Military Foundation, known as Mehmetçik Vakfi.
} 
Stokes argues that it is 'necessary to probe the hypernormativity' of that nationalist negotiation with Müren's gendered persona 'for the contradictions and tensions that lie within it' (Stokes, 2003: 307). As well as the heteronormative investment in Zeki Müren through Turkish melodrama, and the pseudo-autobiographic scholarship and journalistic inquiries, Stokes also refers to the viability of what he calls 'the nostalgic argument spun around' the singer.

'Combin[ing] kitsch and high culture, camp and emotional sincerity, modernity and religious conservatism, visual spectacle and aural intimacy, an East-oriented cosmopolitanism and a West-oriented Turkish nationalism', the public image of Müren as 'the ideal citizen', according to Stokes, is 'capable of absorbing multiple and often contradictory identifications' (2010: 47). Similarly, in her analysis of Müren's films, Umut Tümay Arslan parallels Müren's sexual ambivalence with the ontological ambivalence of 'Turkishness', where the anxieties of unbelonging, in the realm of both sexuality and nationality, motivate ways of foreclosing queer identifications by means of the pathos of nationhood:

If classical Turkish music is the veiled memory of the past, then the image of Zeki Müren is the body which veils the foundation of disavowed Turkishness. (...) The national heterosexual self here gains its voice through the repression and denial of homosexuality, which transforms to a sadomasochistic economy through the provincial masters (masters of taşra) and the dandy (züppe) masters. (...) Zeki Müren gestures to the void, if not a paradox, within Turkishness where sublime and absurd, innocent emotional attachments and obscene pleasures, narcissism and sadomasochism intersect (Arslan, 2010: 19, my translation). 
Turkey's experience of a localised form of modernity and of a never-ending crisis in the secular status of a homogenised citizenship (a crisis cathected by the crossfertilisation of Islam and the modern nation-state) makes the normative pattern of heterosexualities, the body politic, or, more generally, identificatory regimes of genders/sexualities extremely diverse (Kandiyoti, 1997). If idealised national heterosexuality is perturbed and hybridised by various different constructs of heteronormativitity (within contexts such as secularism, nationalism, Islam or globalisation), then in what ways can we rethink the relationship between the queer and the straight in a contemporary Turkish context? Is it possible to translate, and thus localise, queer practice as a project of constant political resistance that actively relates to, in disidentifying with, the heteronormative regimes of gender/sexuality within (both ends of) the dominant dichotomies of contemporary politics in Turkey? What other kinds of 'return' can be claimed from the repressed (Gürbilek 2011)? What archives, what histories of sexual dissidence can be used as a queer dispositif for a strategic return from the collective cultural memory? Can we think today of a cross nurturing dynamics to be mobilised by queer? In particular, what would it mean to be(come) a queer, to queer, to perform 'queer art,' in Turkey after all? What could becoming queer signify in a collective geopolitical memory that has no historic catalyst like Stonewall, or an AIDS crisis to be melancholically reflected upon, to be grieved over, and to act 'militantly' upon (Crimp, 2002)? Is it possible to mourn queer in a queer way? How might a contemporary artist in Turkey, by sublating the particular and the universal, the local and the global, cultivate a queer critique in art? In light of these questions, it can be claimed that Seymen's peculiar act of 
mourning Zeki Müren becomes an act of mourning beyond the figure of Müren per se.

In exposing the violence of hegemonic masculinity and exploiting it with a sadomasochistic erotics, Seymen's art practice prioritises a queer agenda: 'My art is concerned with normalisation of any mode of violence ... violence of the state and the police ... any xenophobic discourse of hate including militarism, transphobia, racist nationalism, class elitism, etc.' (Öğünç, 2007). Seymen's queer vision and method, his strategic erotics and politics of appropriation/exploitation, 'operate through a series of technologies of otherness,' whose critical urge Erden Kosova conceptualises as 'curiosity, cruelty, and contamination', embodied by 'a gaze that observes, that doesn't shun being gazed at, that observes itself (its own act of gazing); a voyeuristic and consequently an exhibitionistic gaze, that looks for the potentially disturbing elements, things that have been labelled as abject, and forces them to surface' (Kosova, 1997: 3).

The logic of surface and the vision of embodied penetration in Seymen's Portrait works to invert the performative of militarist masculinity by enacting a masochistic jouissance. The work genders and eroticises the rumoured encounter that inspired it. The animated encounter in Portrait acts as a commentary on heteronormative masculinity in Turkish society, which the image of Müren is mirroring back: the more exposed the figure is to the penetration of bullets, the more radically visual it becomes. Seymen enacts a method in such a way that the art object functions not 
only to address what seems to have been universally valourised as the discursive patterns of queer theory, praxis and aesthetics, but also to recontextualise and relocalise it, and thus re-write it, from within the context of the contemporary Turkish subject.

I would argue that Portrait of a Pasha enables queer performativity to be read not as hegemonic and universalising but effectively as a 'travelling' concept. Through Seymen's performative and even scatological use of the queer male, portrayed as the receptacle penetrated by militarist ejaculatory virility, hegemonic disembodied masculinity operates as a rematerialised and thus troubled referent in Portrait. In this regard, Seymen's agenda in portraying Müren goes beyond a paranoid urge to expose the homosexual reference. It fictionalises a queer encounter and attempts to form an artistic agency which confronts militarism, and the manner in which it constitutes as nation(ness) and gender.

The constitutive anxiety of heteronormative masculinity is an anxiety of bodily production. According to Calvin Thomas, the fear of liminalised corporeality 'is not so much one of influence, but as one of exfluence, of excorporation, a general anxiety about flux and fluidity, an unease not only about what comes out of the body but also about the ways bodies themselves originally come out' (1996: 13-14). Thomas further claims that 'the masculine productivity as excorporation becomes destruction ... a search for a killable other,' which can possibly be subverted by writing the male body 'as a bodily function': an écriture of masculinity (1996: 18; 
2002). In this sense, the ejaculatory act of firing a gun employed in Seymen's Portrait signifies anxious masculine productivity as penetration, via excorporation. It confronts the masculine with its repudiated other whose visual emergence is the very effect of the penetrative virility enjoyed by the culturally iconic image of Turkish homosexuality. Seymen 'contaminates' the gossip encounter between the soldier and the homosexual by overwhelming the visual discourse with a homoerotic economy of sadomasochism. The portraiture and its logic of penetration work to allegorise sodomy. The haunting image of Müren on canvas comes to function as the 'sodomitical sublime' of Turkish modernity (Munt, 2008: 223-4).

Seymen's portrait is a free-standing work of art. The curatorial location of the art work in the centre of a spatial junction bridging the exhibition paths does not allow the spectator to treat the behind as a behind. It is, bodily and visually, as accessible as the front of the Portrait. The inescapable spectatorial exposure to the behind of the artwork turns the two dimensional surface of the Portrait into an obscene depth of abject flesh. As the Portrait's view from behind also shows (see figure 2), the splinters of wood from gunshots seen on the black panel of the back stand convey a scatological effect, which allows this interpretation of the work to flirt with the artist's subversive intent: an inverted discourse of penetration. The bullet-riddled wooden panel of Seymen's Portrait has a behind that acts as 'a homograph that binds together a physical as well as an epistemological location' (Kemp, 2009: 153). Seymen's queer strategy of anal(ised) anti-militarist sabotage politicises the unutterable 'behind' of Zeki Müren in Turkey's cultural memory, or in other words, 
what body, what body part and what joy the soldier-citizen left behind his discourse. Seymen's gift addresses both the military pashas and the queer pashas in contemporary Turkey.

\section{Militarism and its queer SM exploits:}

The introductory remarks on the peculiar use of the black flag in Seymen's Alliance and the above analysis of the artist's queer allusion to (and erotic exploitation of) militarist nationalism in Portrait of a Pasha would gain further critical dimensions when analysed with Performance for a Poem-2, the artist's video performance of Arif Nihat Asya's well-know poem Flag (Bayrak, 1946). In this performance, Seymen wears a traditional costume that is worn by boys for the circumcision ritual. The artist puts on an SM mask and recites the poem Flag through a sonic device in his mouth that distorts and mediates the sound. The performance acts as a live collaboration where the visual mediation of the artist's body-image is also being distorted. Both sound and image become noise. The subtlety in the treatment of the banal physical presence of the flag in Alliance is replaced here by an aggressive reenactment of the nationalistic pathos in Asya's poem celebrating the image of flag.

0 the white and red ornament of blue skies

My sister's bridal wear, my martyr's final veil

My flag so glaring, so billowy

I've read your poem, will write your poem

I'll dig the graves of whomever

Fixes their eyes upon you

I'll pull down the bird's nest

Which passes without greeting you

My honor, poem, my everything

Choose a place in the world

Where you want to be stand 
Tell me and I will erect you there! ${ }^{4}$

Seymen's body-image, one would contend, performs the Son of Turkey (i.e. the ideal soldier-citizen) and treats it as an embodiment of state ideology. Circumcision in Turkey can be taken as the first collectively ritualised, cultural performance for the male child to gain consciousness of becoming a man, and so the costume in the performance is a strong reference to the perpetual cultural celebration of masculinity in Turkey. Seymen's distorted voice exploits the common image of the performances of school children reading poems (of patriotic sentiment) on national days. The video makes its audience confront, in exaggerating further, the normalised excess and pathos in those performances. The compulsory cultural intersections between hegemonic masculinities and nationalism, technologies of taming or 'schooling' the adolescent body in Turkish culture become objects of appropriation, modes of sadomasochistic jouissance, for the artist.

The audiovisual distortion of the video performance takes place synchronically. The spectator of the live performance does not have a direct visual access to the artist. The event is mediated by Seymen's collaborators, son:DA, who enact a live manipulation of image and sound during the artist's performance. The artist considers the performative setting of his bodily detachment and mediation as an allegory of 'the headquarters of ideology closed to public' (Uncu, 2009, my translation). Ironically, the agenda here is to reverse the normalising effect of

\footnotetext{
4 This extract from Asya's poem Bayrak (1946) is cited from the English subtitles of the artist's video Performance for a Poem 2.
} 
mediation: rather than mimicking the sentiment of martyrdom in Asya's poem, the performances of both Seymen and son:DA agitate and hyperbolise the very violence within the nationalistic pathos. The more the sentiment is sonically enacted by the artist, the more the sound and the videographic image gets chaotic and distorted. Pride and the vulnerability of the circumcised boy in the imagery seem to queer the gendered valencies of nationalism.
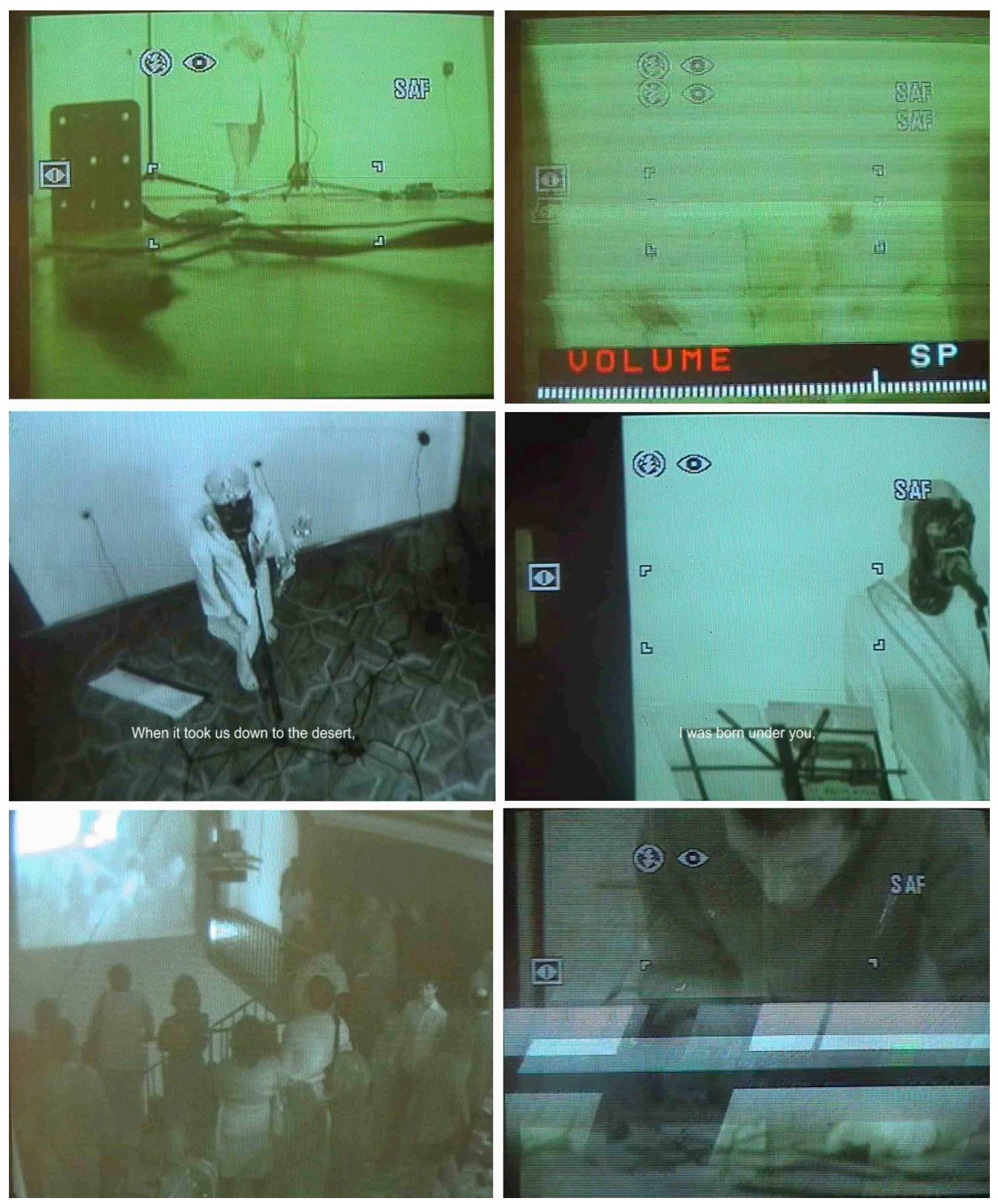


\section{Figure 3.}

Erinç Seymen, Performance for a Poem - 2 (2007)

Reproduced with permission. Courtesy of the artist and RAMPA, Istanbul.

Queer aesthetics prioritise inventing new ways of social relationality, and modes of critical conduct, rather than seeking identity-based paths of resistance. A strong self awareness is at play on the part of contemporary queer studies 'to mobilise a broad social critique of race, gender, class, nationality and religion, as well as sexuality [and] to rethink the relationship between intersectionality and normalisation from multiple points of view' (Eng, Halberstam and Muñoz, 2005: 4-5). Seymen's artworks gesture at possibilities of queer critical practice in contemporary Turkey. The artist enables possible strategies of translating, transposing and diversifying queer into a practice that not merely insists on a local political context but acts as a relational object in its potential to mobilise multiple scales of interpretation and to appropriate the geopolitics of critical theory and of a global/ised contemporary art market.

\section{References:}

Ahmed, S. (2011) 'Problematic Proximities: Or Why Critiques of Gay Imperialism Matter', Feminist Legal Studies, Vol 19, pp. 119-132.

Altman, D. (1996) 'Rupture or Continuity? Internationalization of Gay Identities', Social Text, Vol. 14:3, pp. 77-94. 
Altman, D. (1997) 'Global Gaze/Global Gays’, GLQ, Vol. 3:4, pp. 417-436.

Arslan, U. T. (2010) Mazi Kabrinin Hortlaklarl: Türklük, Melankoli ve Sinema, Istanbul: Metis.

Bersani, L. (1996) Homos, Cambridge: Harvard University Press.

Bersani, L. (1987) 'Is the Rectum a Grave?', October, Vol. 43, pp. 197-222.

Billig, M. (1995) Banal Nationalism, London: Sage.

Crimp, D. (2002) Melancholia and Moralism: Essays on AIDS and Queer Politics, London: MIT Press.

Çakırlar, C. (2013) 'Aesthetics of Self-scaling: Parallaxed Transregionalism and Kutlug Ataman's Art-Practice', Journal of Critical Arts, Vol. 27:6, pp. 684-706.

Çakırlar, C. (2011a) 'Masculinity, Scatology, Mooning and the Queer/able of Gilbert \& George: On the Visual Discourse of Male Ejaculation and Anal Penetration', Paragraph: A Journal of Modern Critical Theory, Vol. 34:1, pp. 86-104.

Çakırlar, C. (2011b) 'Queer Art of Parallaxed Document: Visual Discourse of Docudrag in Kutluğ Ataman's Never My Soull', Screen, Vol. 52:3, pp. 358-375. 
Dean. T. (2000) Beyond Sexuality, Chicago: University of Chicago Press.

Deleuze, G. (1995) Negotiations 1972-1990, trans. Martin Joughin, New York: Columbia University Press.

Eng, D. L., Halberstam, J. \& Muñoz, J. E. (2005) 'Introduction: What's Queer about Queer Studies Now?', Social Text, Vol. 84-85: 3-4, pp. 1-17.

Flannery, D. (2005) 'Queer' Photography and the 'Culture Wars': Robert Mapplethorpe's Queer Aesthetic of the Pair', In D. Holloway \& J. Beck (eds.) American Visual Cultures (pp. 265-73), London: Continuum.

Gürbilek, N. (2011) The New Cultural Climate in Turkey: Living in a Shop Window, London and New York: Zed Books.

Haritaworn, J., Tauqir, T. \& Erdem, E. (2008) ‘Gay Imperialism: Gender and Sexuality Discourse in the "War on Terror" In A. Kunstman and E. Miyake (eds.) Out of Place: Interrogating Silences in Queerness/Raciality (pp. 71-95), York: Raw Nerve Books.

Kandiyoti, D. (1997) 'Gendering the Modern: On Missing Dimensions in the Study of Turkish Modernity' In S. Bozdoğan and R. Kasaba (eds.) Rethinking Modernity and National Identity in Turkey (pp. 113-32), London: University of Washington Press. 
Kemp, J. (2009) 'Schreber and the Penetrated Male', In C. Nigianni and M. Storr (eds.) Deleuze and Queer Theory (pp. 150-67), Edinburgh: Edinburg University Press.

Kosova, E. (2002) 'Technologies of Otherness', In Erinç Seymen (pp. 2-17), Istanbul: galerist.

Kosova, E. (2009) 'Slow Bullet II', Red Thread, Vol. 1:1, n.p. Retrieved from http://www.red-thread.org/en/article.asp?a=26. Last access: 28/11/2014.

Massad, J. (2002) 'Re-Orienting Desire: The Gay International and the Arab World', Public Culture, Vol. 14:2, pp. 361-85.

Munt, S. R. (2008) Queer Attachments: The Cultural Politics of Shame, Hampshire: Ashgate.

Muñoz, J. E. (1999) Disidentifications: Queers of Color and Performance of Politics, Minneapolis, MN: University of Minnesota Press.

Öğünç, P. (Interviewer) \& Seymen, E. (Interviewee). (2009, April 7) Zaten hadım edilmiş bir kuşağın çocuklarıyız [We are the children of a castrated generation anyway: An Interview with Erinç Seymen]. Radikal. 
Rogoff, I. (2010) 'Regional Imaginings', In H. Amirsadeghi (ed.) Unleashed: Contemporary Art from Turkey (pp. 48-55), London: TransGlobe Publishing.

Stokes, M. (2010) The Republic of Love: Cultural Intimacy in Turkish Popular Music, London and Chicago: The University of Chicago Press.

Stokes, M. (2003) 'The Tearful Public Sphere: Turkey’s 'Sun of Art' Zeki Müren', In T. Magrini (ed.) Music and Gender: Perspectives from the Mediterranean (pp. 307-28), Chicago: The University of Chicago Press.

Thomas, C. (1996) Male Matters: Masculinity, Anxiety and the Male Body on the Line, Urbana: University of Illinois Press.

Thomas, C. (2002) ‘Must Desire Be Taken Literally?', Parallax, Vol. 8:4, pp. 46-56.

Traub, V. (2008) 'The Past Is a Foreign Country? The Times and Spaces of Islamicate Sexuality Studies', in K. Babayan and A. Najmabadi (eds) Islamicate Sexualities: Translations across Temporal Geographies of Desire (pp. 1-40), London and Cambridge: Harvard University Press. 
Uncu, E. A. (Interviewer) \& Seymen, E. (Interviewee). (2009, June 10). Otoritenin tüm 'ikna odaları' bu sergide [All 'persuasion rooms' of authority are in this show]. Radikal. 